\title{
PENGELOLAAN KELAS DALAM PEMBELAJARAN BAHASA INDONESIA DI KELAS VIII SMP NEGERI 10 KOTA BENGKULUTAHUN AJARAN 2016/2017
}

\author{
Githa Ulandari ${ }^{1}$, Suhartono ${ }^{2}$, dan Arono $^{3}$ \\ ${ }^{1,2,3}$ Program Studi Pendidikan Bahasa dan Sastra Indonesia \\ Jurusan Pendidikan Bahasa dan Seni \\ FKIP Universitas Bengkulu \\ Ulandari githa@yahoo.co.id
}

\begin{abstract}
Abstrak
Pengelolaan kelas merupakan sebuah upaya real untuk mewujudkan proses atau kegiatan belajar mengajar yang efektif. Dengan pengelolaan kelas yang baik diharapkan dapat mendukung tercapainya tujuan pembelajaran dan memberikan pengaruh positif yang secara langsung menunjang terselenggaranya proses belajar mengajar di kelas. Agar memberikan dorongan dan rangsangan terhadap siswa dalam belajar, kelas perlu dikelola sebaik-baiknya. Kegiatan yang perlu dilaksanakan dalam mengelola kelas, yaitu penataan siswa di dalam kelas, penataan ruang, menciptakan disiplin kelas, menunjukan sikap tanggap.Penelitian ini bertujuan untuk mengetahui pengelolaan kelas pada mata pelajaran Bahasa Indonesia yang berkaitan dengan pemeliharaan kondisi belajar optimal (preventif), pengembalian kondisi belajar (represif). Pengumpulan data dengan pengamatan observasi proses pembelajaran. Wawancara dengan guru mata pelajaran yang bersangkutan, dan dengan studi dokementasi berupa rencana program pembelajaran (RPP). Hasil penelitian yang didapat, kemudian dianalisis berdasarkan metode observasi dan studi dokumentasi dan. Hasil penelitian menunjukkan bahwa pengelolaan kelas pada mata pelajaran bahasa Indonesia di SMP Negeri 10 kota Bengkulu yang berkaitan dengan pemeliharaan kodisi belajar optimal (preventif) yang terdiri dari 6 aspek dan pegembalian kondisi belajar (represif) yang terdiri dari 3 aspek sudah dilaksanakan oleh guru.
\end{abstract}

\section{Kata Kunci: Pengelolaan kelas, pemeliharaan kondisi belajar optimal (preventif), pengembalian kondisi belajar (represif)}

\begin{abstract}
Classroom management is a real effort to realize an effective teaching or learning process. With good class management is expected to support the achievement of learning objectives and provide a positive influence that directly support the implementation of teaching and learning in the classroom. In order to provide encouragement and stimulus to students in learning, the class needs to be managed as well as possible. Activities that need to be implemented in managing the class, namely the arrangement of students in the classroom, spatial arrangement, creating classroom discipline, showing attitude responsiveness. This study aims to determine the management of classes in Indonesian subjects related to the maintenance of optimal learning conditions (preventive) Learning conditions (repressive). Data collection with observation of learning process observation. Interviews with relevant subject teachers, and with a study of the form of a learning program plan (RPP). The results obtained, then analyzed based on the method of observation and documentation studies and. The results showed that classroom management in Indonesian language subjects in SMP Negeri 10 Bengkulu city related to the maintenance of optimal learning (preventive)
\end{abstract}


which consists of 6 aspects and return of learning condition (repressive) consisting of 3 aspects already implemented by the teacher.

Keywords: Classroom management, maintenance of optimal learning conditions (preventive), return of learning conditions (repressive)

\section{PENDAHULUAN}

Sebagai lembaga pendidikan, sekolah sangat membutuhkan tenaga ahli dalam bidang mengajar yakni guru. Guru merupakan faktor yang sangat penting dalam pendidikan formal pada umumnya karena bagi siswa sering dijadikan tokoh teladan.

Guru seharusnya memiliki perilaku dan kemampuan yang memadai untuk mengembangkan siswanya secara utuh. Untuk melaksanakan tugasnya secara baik sesuai dengan profesi yang dimilikinya, guru perlu menguasai berbagai hal kompetensi yang dimilikinya, termasuk kemampuan dalam mengelola kelas.

Tindakan pengelolaan kelas seorang guru akan efektif apabila ia dapat mengidentifikasi dengan tepat hakekat masalah yanng sedang dihadapi sehingga pada gilirannya ia dapat memilih strategi yang tepat pula. Masalah pengelolaan kelas menurut Zuldafriah (2012:20) pada dasarnya dapat dikelompokkan menjadi dua kategori yaitu masalah individual dan masalah kelompok.

Berdasarkan pengamatan peneliti di sekolah, pengelolaan kelas dalam pembelajaran bahasa Indonesia, guru masih belum melaksanakan pengelolaan kelas dengan baik. Kenyataan tersebut mendorong peneliti memberikan inovasi pengelolaan kelas dalam pembelajaran bahasa Indonesia, yaitu berupa pemeliharaan kondisi belajar optimal (preventif) dalam pembelajaran bahasa Indonesia, pengembalian kondisi belajar (represif) dalam pembelajaran bahasa Indonesia.

Djamarah (2014:174) menyatakan bahawa pengelolaan kelas adalah salah satu tugas guru yang tidak pernah ditinggalkan. Pengelolaan kelas merupakan keterampilan guru untuk menciptakan dan memelihara kondisi belajar yang optimal dan mengembalikan ke kondisi yang optimal jika terjadi gangguan, baik dengan cara mendisiplinkan ataupun melakukan kegiatan remedial (Asril, 2011:72). Dengan kata lain, ialah kegiatan-kegiatan untuk menciptakan dan mempertahankan kondisi yang optimal bagi terjadi proses belajar mengajar. Dalam hal ini misalnya penghentian tingkah laku anak didik yang menyelewengkan perhatian kelas, pemberian hadiah bagi ketepatan waktu penyelesaian tugas oleh atau penetapan norma kelompok yang produktif.

Keterampilan yang berhubungan dengan pengembangan kondisi belajar yang optimal, meliputi: a) Menunjukan sikap tanggap. Dalam tugasnya mengajar, guru harus terlibat secara fisik maupun mental dalam arti guru selalu memiliki waktu untuk semua perilaku positif maupun perilaku negatif, b) Membagi perhatian. Guru harus mampu membagi perhatian ke semua peserta didik, perhatian itu dapat bersifat visual maupun bersifat verbal, c) Memusatkan perhatian kelompok. Mempertahankan dan meningkatkan keterlibatan peserta didik dengan cara memusatkan kelompok kepada tugas-tugasnya dari waktu ke waktu, d) Memberi petunjuk-petunjuk yang jelas. Petunjuk ini dapat dilakukan untuk materi yang disampaikan, tugas yangdiberikan dan perilaku-perilaku peseta didik lainnya yang berhubungan baik langsung maupun tidak langsung pada pelajaran, e) Menegur. Tegurlah peseta didik bila mereka menunjukan perilaku 
yang mengganggu atau menyimpang, f) Memberi penguatan. Perilaku peserta didik baik yang positif maupun negatif perlu memperoleh penguatan.

Keterampilan mengembalikan kondisi belajar mengajar, meliputi: a) Modifikasi tingkah laku. Perilaku peserta didik yang mengganggu dianalisis kemudian ditentukan langkah-langkah untuk remedial, b) Pengelolaan kelompok. Dalam menangani masalah pengelolaan kelas, guru dapat memanfaatkan pendekatan pemecahan masalah kelompok, c) Menemukan dan memecahkan tingkah laku yang menimbulkan masalah. Guru dapat melaksanakan beberapa cara untuk mengendaliakn tingkah laku mengganggu yang muncul.

\section{METODE}

Metode dalam penelitian ini ialah metode deskriptif kualitatif. Metode deskriptif yaitu metode yang diarahkan untuk memecahkan masalah dengan cara memaparkan atau menggambarkan apa adanya hasil penelitian. Tujuan penelitian deskriptif adalah untuk membuat pecandraan atau deskripsi secara sistematis, faktual, dan akurat mengenai situasi atau kejadian dan fenomena yang sering terjadi ketika penelitian sedang dilaksanakan.

Penelitian ini dilaksanakan pada siswa kelas VIII SMPN 10 Kota Bengkulu tahun ajaran 2016/2017. Waktu penelitian ini dilaksanakan pada bulan Februari sampai dengan bulan Maret. Subjek penelitian ini ialah guru dan siswa kelas VIII dalam pembelajaran bahasa Indonesia serta interaksi yang terjadi pada saat melaksanakan kegiatan pembelajaran bahasa Indonesia berdasarkan pembagian kelas dilihat berdasarakan ketuntasan SK dan KD di SMP Negeri 10 Kota Bengkulu.

\section{HASIL DAN PEMBAHASAN}

Penelitian ini ada 2 (dua) aspek yaitu (1) pemeliharaan kondisi belajar optimal (Preventif), (2) pengembalian kondisi belajar (Represif). Data yang dijadikan dasar hasil penelitian ini adalah pengelolaan kelas pada mata pelajaran bahasa Indonesia di kelas VIII A dan VIII B yang diperoleh dari hasil observasi, dokumen-dokumen berdasarkan kategori yang sesuai dengan masalah penelitian.

Tahap pertama yang dilakukan peneliti dalam penelitian ini yaitu observasi 2 (dua) aspek, (1) pemeliharaan kondisi belajar optimal (Preventif), (2) pengembalian kondisi belajar (Represif).

Data komponen pemeliharaan kondisi belajar optimal (preventif), sesuai dengan hasil observasi selama 4 (empat) kali, yaitu; menunjukan sikap tanggap, membagi perhatian, memusatkan perhatian kelompok, memberi petunjukpetunjuk yang jelas, menegur, memberi penguatan.

\section{Menunjukan Sikap Tanggap}

Berdasarkan observasi yang dilakukan peneliti dalam pelaksanaan pembelajaran bahasa Indonesia di kelas VIII A guru tidak selalu menunjukan sikap tanggap dalam tugas mengajar, karena siswa di kelas VIII A memiliki karakter yang baik dan mengerti situasi dan kondisi pada saat proses pembelajaran berlangsung. Terlihat pada saat proses belajar mengajar ketika guru menjelaskan materi kepada siswa, siswa tiba-tiba ribut dan guru langsung memandang dan begerak mendekati siswa yang ribut siswa langsung diam tanpa guru memberi pernyataan yang mengandung ancaman. berdasarkan observasi yang dilakukan di kelas VIII B, guru menunjukkan sikap tanggap, karena siswa di kelas B memiliki karakter yang kurang baik. Telihat pada saat proses pembelajaran siswa ribut pada saat guru menjelaskan materi, guru melakukan cara 
memandang secara saksama, gerak mendekati dan guru pun memberikan pertanyaan kepada siswa. Pertanyaan tersebut mengandung ancaman bagi siswa "Ya sudah saya tunggu sampai kalian diam, silahkan ribut."

\section{Membagi Perhatian}

Berdasarkan observasi yang dilakukan peneliti dalam pelaksanaan pembelajaran bahasa Indonesia di kelas VIII A dan VIII B bahwasanya guru selalu memberikan perhatian kepada siswa pada saat proses pembelajaran berlangsung baik itu perhatian bersifat visual maupun bersifat verbal. Guru memberikan perhatian bersifat visual terlihat pada saat guru menjelaskan materi yang pertama setelah materi pertama selesai guru sampaikan dari perhatian siswa dan guru mengubah pandangannnya tanpa kehilangan perhatian pada materi yang pertama guru melirik materi yang kedua pandangan ini dilakukan guru terhadap sekelompok siswa.

Guru memberikan perhatian bersifat verbal terilahat pada saat guru menyampaikan materi pertama dan materi yang kedua, sebelumnya guru memberikan materi yang kedua guru terlebih dahulu memberi pertanyaan kepada siswanya tentang materi yang pertama. Pertanyaan tersebut seperti "Apa yang dimaksud dengan membaca ekstensif?", guru memberikan pertanyaan supaya guru tahu apakah siswa sudah mengerti dengan materi yang guru sampaikan, jika siswa sudah mngerti atau sudah tahu apa materi yang disampaikan oleh guru tersebut maka guru melirik ke materi yang kedua tanpa kehilangan perhatian pada materi yang pertama.

\section{Memusatkan Perhatian Kelompok}

Berdasarkan observasi yang dilakukan peneliti dalam pelaksanaan pembelajaran bahasa Indonesia di kelas
VIII A dan VIII B bahwasanya guru setelah menjelaskan materi yang telah ia sampaikan, selanjutnya guru memberikan tugas kepada siswa, guru juga memberikan penjelasaan kepada siswa bahwasanya siswa harus bertanggung jawab siswa akan tugasnya-tugasnya. Hal tersebut agar siswa lebih giat lagi dalam belajar dan mengerjakan tugas-tugas yang diberikan oleh guru.

\section{Memberi Petunjuk-petunjuk yang Jelas}

Berdasarkan observasi yang dilakukan peneliti dalam pelaksanaan pembelajaran bahasa Indonesia di kelas VIII A dan VIII B bahwasanya pada saat proses belajar mengajar berlangsung yaitu pada saat guru memberikan penjelasan materi kepada siswa dengan secara jelas, setelah guru menjelaskan materi guru tersebut bertanya kepada siswanya "Apakah sudah mengerti?", dengan seperti itu agar guru tahu apakah siswa sudah mengerti dengan materi yang ia sampaikan atau belum. Serta guru memberikan putunjuk yang jelas dengan tugas yang ia berikan kepada siswanya.

\section{Menegur}

Berdasarkan observasi yang dilakukan peneliti dalam pelaksanaan pembelajaran bahasa Indonesia di kelas VIII A dan VIII B bahwasanya pada saat proses pembelajaran berlangsung guru tidak memberi teguran kepada siswa yang melanggar tata tertib kelas, yaitu masih ada terdapat siswa tidak mencatat materi yang guru jelaskan padahal guru menyuruh siswa mencatat apa yang guru jelaskan dan masih banyak siswa yang tidur-tiduran pada saat proses pembelajaran berlangsung. Juga masih ada terdapat siswa yang keluar masuk kelas pada saat proses pembelajaran berlangsung, serta masih banyak siswa yang ngobrol saat guru menjelaskan materi di depan kelas. 


\section{Memberi Penguatan}

Berdasarkan observasi yang dilakukan peneliti dalam pelaksanaan pembelajaran bahasa Indonesia di kelas VIII A dan VIII B bahwasanya penguatan yang guru berikan yaitu dengan penguatan verbal, misalnya guru harus mampu mengatakan siswa itu bagus apabila yang dilakukan siswa itu memang bagus, kemudian juga sesekali guru boleh menyampaikan verbal negatif untuk mengatakan kepada siswa bahwa apa yang dilakukan itu salah, jadi berupa sangsi, misalnya menuliskan sesuatu yang menjadi kesalahan itu sebanyak mungkin di buku latihan mereka, dengan cara seperi itu agar ada efek jera terhadap siswa yang berprilaku negatif. Kemudian non verbal guru bisa memberikan cap jempol, misalnya mengangkat jempol apabila dapat menjawab pertanyaan apa yang kita sampaikan.

Data komponen pengembangan kondisi belajar (represif), sesuai dengan hasil observasi selama 4 (empat) kali. Meliputi modifikasi tingkah laku, pengelolaan kelompok, menemukan dan memecahkan tingkah laku yang menimbulkan masalah.

\section{Modifikasi Tingkah Laku}

Berdasarkan observasi yang dilakukan peneliti dalam pelaksanaan pembelajaran bahasa Indonesia di kelas VIII A dan VIII B bahwasanya pada saat proses belajar mengajar berlangsung terdapat siswa dengan tingkah laku yang tidak baik guru mendekati siswa tersebut dan menasehatinya, jika siswa tidak mendengar nasehati dari guru. Guru menempuh dengan cara-cara Conselor.

\section{Pengelolaan Kelompok}

Berdasarkan observasi yang dilakukan peneliti dalam pelaksanaan pembelajaran bahasa Indonesia di kelas VIII A dan VIII B bahwasanya guru pada saat di dalam kelas tidak mengelola kelompok belajar siswa, sehingga tidak ada memanfaatkan pendekatan pemecahan masalah kelompok, karena siswa belajar perindividu.

\section{Menemukan dan Memecahkan Tingkah Laku yang Menimbulkan Masalah}

Berdasarkan observasi yang dilakukan peneliti dalam pelaksanaan pembelajaran bahasa Indonesia di kelas VIII A dan VIII B bahwasanya ketika ada tingkah laku siswa yang menimbulkan masalah guru terlebih dahulu memberikan teguran jika teguran tidak dihiraukan siswa, guru mendekati siswa yang bermasalah tersebut dan menanyakan apa sebab-sebab perilaku itu muncul selanjutnya guru menemukan pemecahan masalah tersebut. Terlihat pada saat antara siswa di kelas mengalami masalah terlebih dahulu guru menegur mereka agar mereka diam, karena dengan teguran dari guru tidak dihiraukan siswa, guru mendekati siswa yang bermasalah tersebut dan menanyakan apa sebab-sebab perilaku itu muncul, setelah itu guru memberikan pemecahan masalah siswa tersebut.

\section{PENUTUP}

\section{Kesimpulan}

Berdasarkan hasil penelitian dan pembahasan dapat disimpulkan sebagai berikut:

1. Pemeliharaan kondisi belajar optimal (preventif) dalam pembelajaran bahasa Indonesia di kelas VIII A dan VIII B sudah dilaksanakan oleh guru. Pemeliharaan belajar optimal (preventif) terdiri dari 6 aspek, yang terdiri dari beberapa aspek sebagai berikut: (1) menunjukkan sikap tanggap, (2) membagi perhatian, (3) memusatkan perhatian kelompok, (4), memberi petunjuk-petunjuk yang jelas, (5) menegur, (6) memberi penguatan. 
2. Pengembalian kondisi belajar (represif) dalam pembelajaran bahasa Indonesia di kelas VIII A dan VIII B sudah dilaksanakan oleh guru. Pengembalian kondisi belajar (represif) terdiri dari 3 aspek, yang terdiri dari beberapa aspek sebagai berikut: (1) modifikasi tingkah laku, (2) pengelolaan kelompok, menemukan dan memecahkan tingkah laku yang menimbulkan masalah.

\section{Saran}

Berdasarkan hasil kesimpulan yang telah dikemukakan sebelumnya, maka dapatlah kiranya diajukan beberapa saran dengan harapan dapat memberikan manfaat sebagi berkut:

1. Adanya kerja sama yang baik antara pihak sekolah, guru maupun siswa dalam mewujudkan pengelolaan kelas yang baik agar menciptakan situasi dan kondisi yang optimal dalam belajar sehingga dapat terarah kepada tujuan pendidikan yang diharpkan.
2. Bagi pihak pemerintah ataupun sekolah, memberikan bantuan (tambahan) dan mengikutsertakan guru dalam peningkatan kemampuan dan keterampilan melalui pendidikan dan pelatihan profesi, pengaturan dan pelatihan secara regional atau nasional. Selain itu perlu adanya dorongan, penghargaan, dan perhatian yang lebih baik guru yang aktif dalam bidang organisasi atau manapun.

\section{DAFTAR PUSTAKA}

Asril, Zainal. 2011. Micro Teaching. Jakarta: Rajawali Pers.

Djamarah, Syaiful Bahri. 2014. Strategi Belajar Mengajar. Jakarta: Rineka Cipta.

Zuldafriah. 2012. Strategi \& Pendektan Pengelolaan Kelas. Surakarta: Yuma Pustaka. 